\title{
First Report of the Ticks Haemaphysalis punctata Canestrini et Fanzago, 1878, Haemaphysalis parva (Neumann, 1897) and Dermacentor marginatus (Sulzer, 1776) (Acari, Amblyommidae) from Humans in Lebanon
}

\author{
Martin Raad ${ }^{1,2} \cdot$ Dany Azar $^{2} \cdot$ M. Alejandra Perotti ${ }^{1}[$
}

Received: 8 October 2019 / Accepted: 14 December 2019 / Published online: 20 January 2020

(c) The Author(s) 2020

\begin{abstract}
Purpose Knowledge on ticks infesting humans is scarce for the middle East. In this work, tick specimens (Acari: Amblyommidae) infesting humans in Lebanon were identified.

Methods Ticks that were found on humans were received in the Lebanese University, Faculty of Sciences. The specimens were preserved in alcohol for their further morphological identification.

Results Three tick species were identified: a red sheep tick Haemaphysalis punctata Canestrini et Fanzago, 1878, a Mediterranean ear tick H. parva (Neumann, 1897), and an ornate sheep tick Dermacentor marginatus (Sulzer, 1776); all isolated from human hosts.

Conclusion This is the first report of Haemaphysalis punctata, H. parva and Dermacentor marginatus infesting humans from Central and North Lebanon.
\end{abstract}

Keywords Tick $\cdot$ Acari $\cdot$ Amblyommidae $\cdot$ Lebanon $\cdot$ Pathogens $\cdot$ Mites

Ticks are ectoparasites infesting ruminants, livestock and humans all over the world, with records in many European and less frequently in Mediterranean countries i.e. Spain, Turkey, Romania, Italy, Iran, Palestine $[1-4,6,8,14,16]$. Reports are rare in the East Mediterranean region. In Lebanon, to the best of our knowledge, ticks infesting humans are still not reported, herein we present the first report of ticks collected on humans.

In late August 2017, a female ornate sheep tick was found on the head of a little boy at Qanat Bakish (Metn District; Mount Lebanon Governate, Central Lebanon), at $1800 \mathrm{~m}$ above sea level, $43 \mathrm{~km}$ North-East of Beirut. Based on the keys of Estrada-Peña et al. [10] and Mariana et al. [17], the female specimen (Fig. 1) was assigned to Dermacentor

M. Alejandra Perotti

m.a.perotti@ reading.ac.uk

1 Ecology and Evolutionary Biology Section, School of Biological Sciences, University of Reading, Whiteknights, Reading RG6 6AS, Berkshire, UK

2 Earth and Life Sciences Department, Faculty of Sciences II, Lebanese University, Fanar, Mount Lebanon, Lebanon marginatus (Sulzer, 1776). Morphological, diagnostic features were confirmed: a small gnathosoma with small mouthparts; basis capituli with straight lateral margins; porose area shape narrow oval; palp article 2 posterior spur absent from dorsal surface; eyes always present and large; scutum of oval shape with white ornamentation; coxae I external and internal spurs gap located medium with the external spur slightly shorter than the interior spur.

Later on, in January 2018, a red sheep tick was collected from the shoulder of an adult man in Mansourieh (Metn District; Mount Lebanon Governate, Central Lebanon). The infestation occurred at $250 \mathrm{~m}$ above sea level, $9 \mathrm{~km}$ SouthEast of Beirut. Based on the keys of Estrada-Peña et al. [10] and Hosseini-Chegeni et al. [14], the female tick was identified as Haemaphysalis punctata Canestrini et Fanzago, 1878 (Fig. 2a). There were no differences with diagnostic characters such as a small gnathosoma (Fig. 2b, red arrow), palp articles 2 broad but not too much extended (Fig. 3 blue arrow), basis capituli with straight lateral margins (Fig. 3 red arrow), scutum of oval shape (Fig. 3 green arrow), spiracular plates large and posterior to leg IV (Fig. 2b green arrow), and spurs of coxae IV distinct (Fig. 2b blue arrow). 

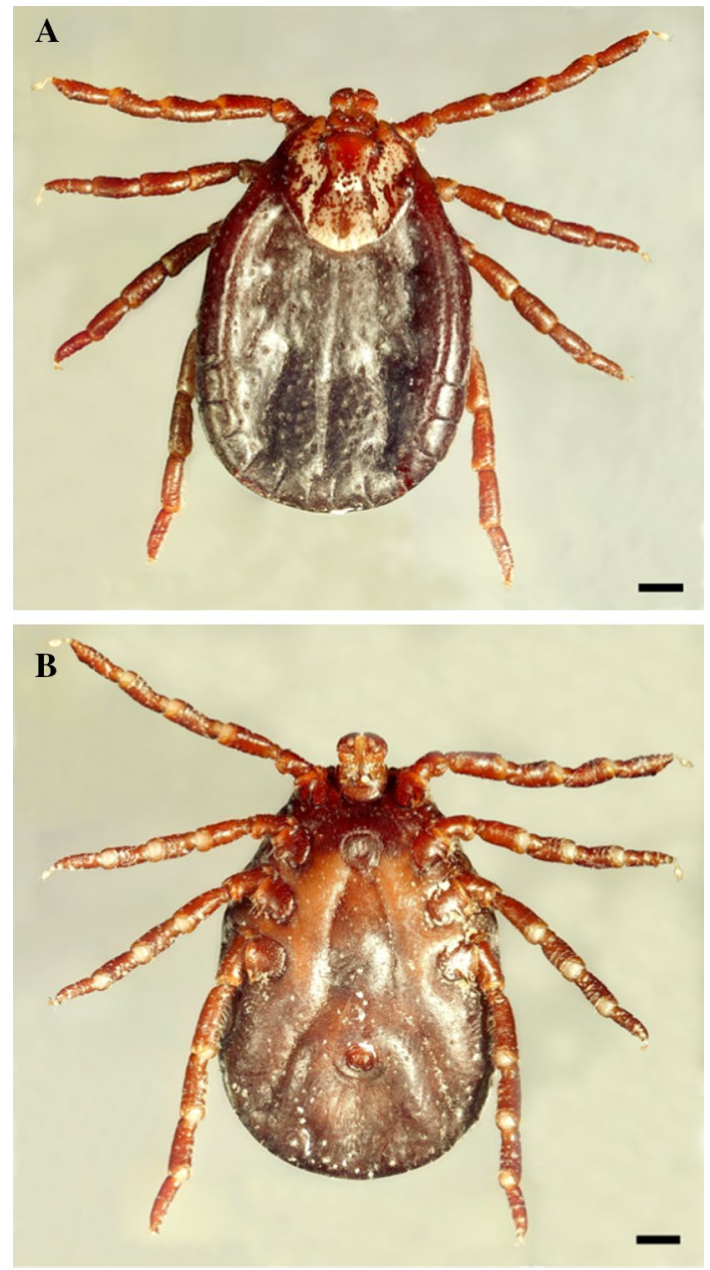

Fig. 1 Adult female Dermacentor marginatus. a Dorsal view, scale bar $0.6 \mathrm{~mm}$. b Ventral view, scale bar $0.6 \mathrm{~mm}$
Another species of Haemaphysalis sp. was found on October 4th 2018, collected on the hand of an adult male in Ehden Natural Reserve, North Lebanon, at $1250 \mathrm{~m}$ above sea level, $110 \mathrm{~km}$ North-East of Beirut. Using the keys of Hosseini-Chegeni et al. [14], a male was identified as a Mediterranean ear tick, Haemaphysalis parva (Neumann, 1897) (Fig. 4). The following features confirm the species: small gnathosoma; no pseudoscutum; palp article 2 without spur from dorsal surface and its lateral palpal segment is angled but not much extended; lateral palpal segment 2 width is wider than basis capituli; palpal segment 3 are straight not pincer-like; large spiracular plates are posterior to leg IV; anal grove has round shape instead of $\mathrm{V}$ shape; coxae I without gap in its spur; and coxae IV spur is short and not longer than coxae I-III.

The red sheep tick $H$. punctata Canestrini et Fanzago, 1878 is a three-host tick with a life cycle lasting between one to three years (Estrada-Peña 2004). Ruminants and humans are its main hosts (Estrada-Peña 2004; [6, 8, 9]. In fact, $H$. punctata is known from many European, North African, Asian and Mediterranean countries-Palearctic realm (Estrada-Peña 2004; [1, 4, 5, 9, 11, 13, 16, 21]. Recently, many studies in the Middle East have reported $H$. punctata infesting humans; for instance, Turkey [6, 16], Palestine, Iraq [8], Iran [14], Sicily [3] and Israel [15]. Although H. punctata occurrence in Lebanon was lately reported by Dabaja et al. [7] and on ruminants, its finding on humans (mainly remains) has not been recorded yet from this country.

The ornate sheep tick D. marginatus (Sulzer, 1776) is a three-host tick with a complete life cycle of about one year. Its adult stage infests ruminants and dogs (EstradaPeña 2004). Nevertheless, humans, rodents and birds are known hosts of its immature stages $([8,9,23,26]$. The
Fig. 2 Adult female Haemaphysalis punctata. a Dorsal view, scale bar $1 \mathrm{~mm}$. b Ventral view, scale bar $1 \mathrm{~mm}$; red arrow indicates the small gnathosoma; green arrow indicates the large spiracular plates; blue arrow indicates the spurs of coxa IV
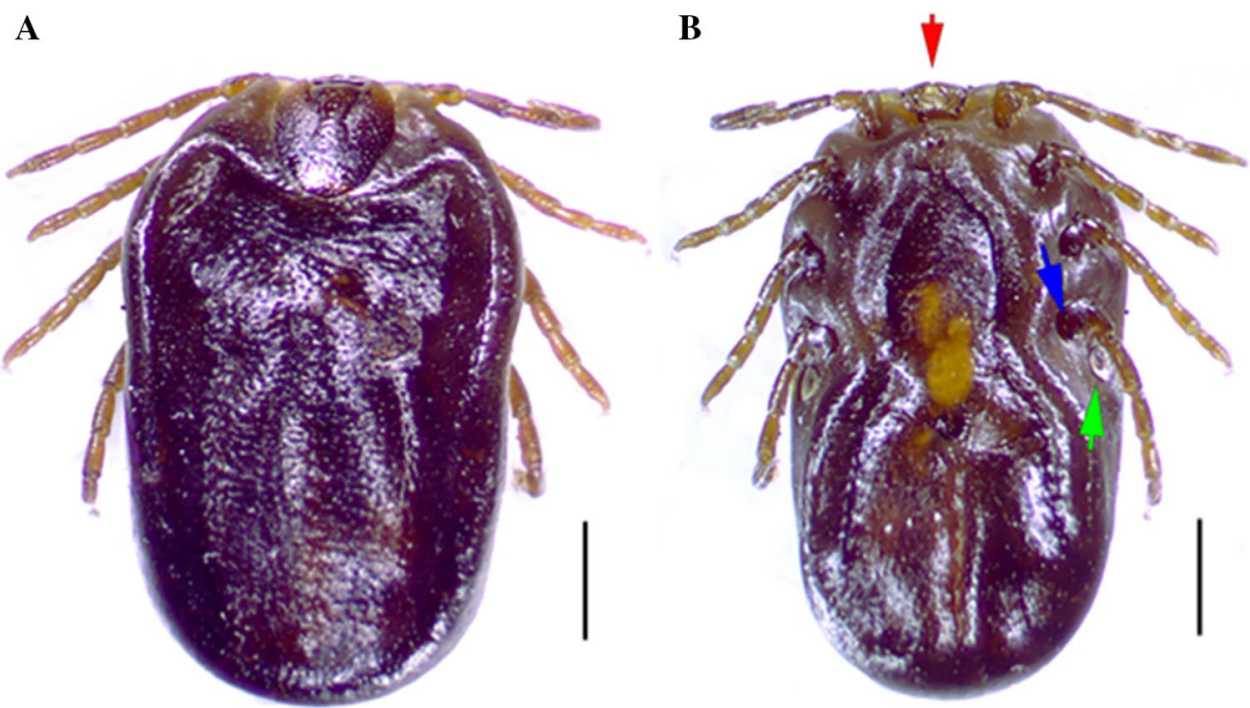
Fig. 3 Detailed dorsal view of the apical part of adult female Haemaphysalis punctata.

Red arrow indicates the basis capituli; green bracket indicates the oval scutum; and blue arrow indicates the palp segments. Scale bar $1 \mathrm{~mm}$

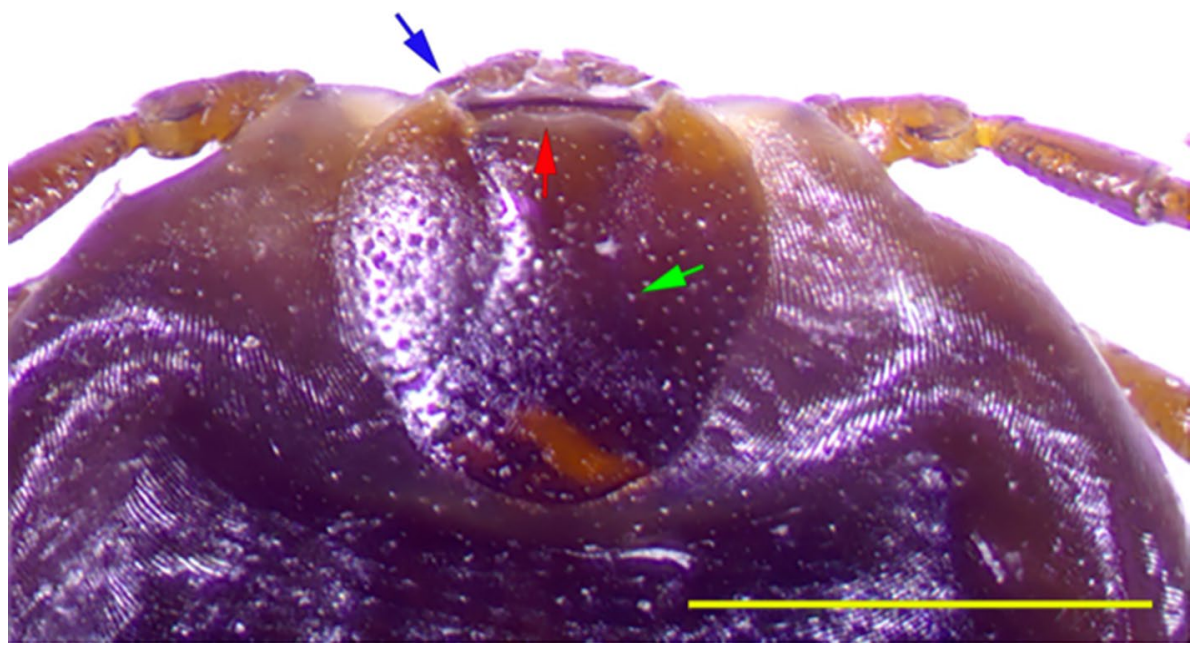

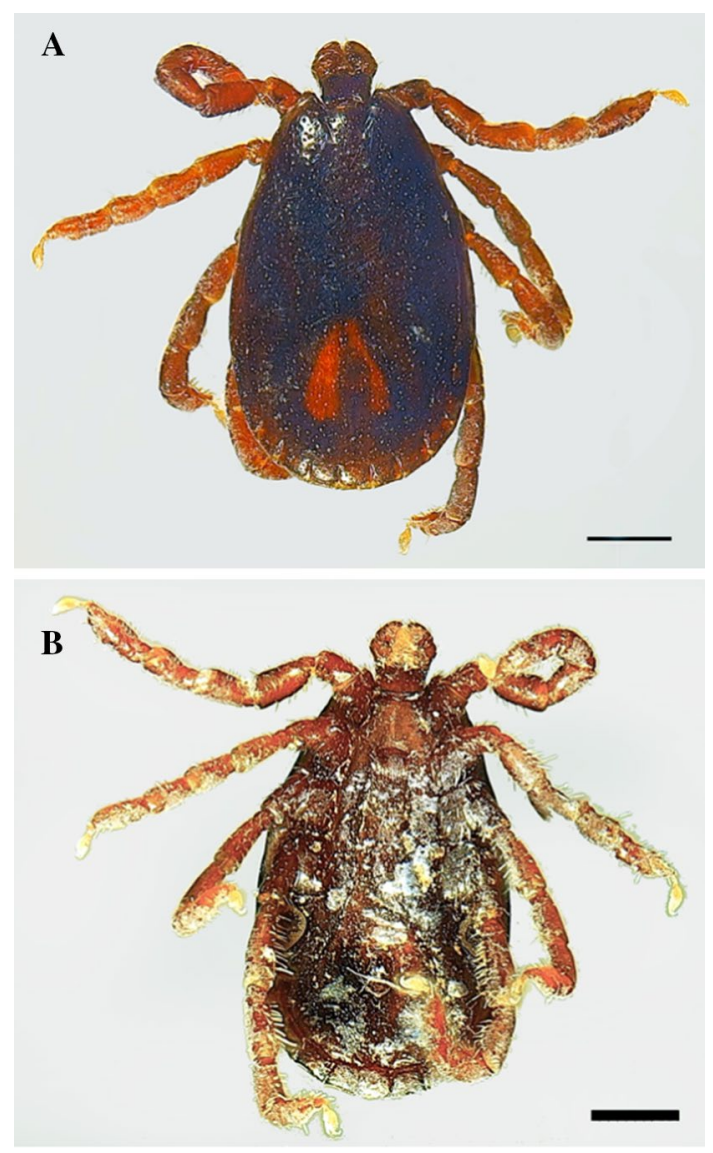

Fig. 4 Adult male Haemaphysalis parva. a Dorsal view, scale bar $0.5 \mathrm{~mm}$. b Ventral view, scale bar $0.5 \mathrm{~mm}$

species distribution includes the European, North African, and Mediterranean countries - the Palearctic region-as it is concentrated in environments of oak and pine vegetation, of optimal (thermophilic) requirements, especially when compared to other accompanying tick species i.e. I. ricinus and $H$. punctata (Estrada-Peña 2004; [1, 9, 13, 14, 16, 21, 23]. Even though several authors reported this tick infesting humans in Europe, Turkey, central Asia and Morocco (Estrada-Peña 2004, [3, 4, 8, 9, 22, 26], D. marginatus in Lebanon have occurred on ruminants from Baalbeck-El Hermel and Mount Lebanon Governates, but not on humans [7], until now.

Similarly, the Mediterranean ear tick H. parva (Neumann, 1897), a three-host tick, is found in the Mediterranean mountains and forests on high altitudes with high humidity level found in Turkey, Israel, Italy, Greece and other countries, hosting livestock and with human presence as well $[6$, $16,18,20,21,24,25]$. Parasitism of $H$. parva occurs during autumn, winter and spring with a peak in October and November [25]. While Bursali et al. [6] and Keskin et al. [16] have mentioned $H$. parva among the feeding ticks on humans in Turkey and Dabaja et al. [7] have cited many ticks found in Lebanon from livestock where $11.4 \%$ were $H$. punctata. Hence, no $H$. parva was cited from Lebanon till now. This is the first report of ticks found on humans in Lebanon, and of especial note is the finding of this rare species, H. parva (Neumann, 1897).

Ticks are generally causative agents of cross-infections in cattle, sheep, ruminants and humans. In the case of $H$. punctata, there is debate about its vector capability. Estrada-Peña et al. [10] and Dabaja et al. [7] suggested that $H$. punctata may transmit Babesia and Theileria species causing disease to humans [12]. Also, Andersson et al. [1] pointed out for tick-borne pathogens such as Hepatozoon canis related to $H$. punctata infesting animals in central Romania. Moreover, Estrada-Peña and Jongejan [9] and de la Fuente et al. [8] mentioned that Tick-Borne Encephalitis (TBE) virus and Crimean-Congo Hemorrhagic Fever (CCHF) virus may be transmitted by $H$. punctata as well.

Estrada-Peña et al. [10] and Blanda et al. [3] mentioned that D. marginatus can transmit Rickettsia conori and $R$. 
aeschlimannii to humans, respectively, causing tick typhus or boutonneuse fever. Parola and Raoult [22] claimed the presence of Francisella tularensis in D. marginatus ticks while infesting humans in Europe, North Africa and Central Asia. Further, Andersson et al. [1] and Keskin et al. [16] declared the occurrence of Rickettsia raoultii in one case, and $R$. slovaca and CCHF virus in another, via D. marginatus infesting humans in Romania and Turkey, respectively. Other publications stated that CCHF virus and $R$. slovaca were identified from D. marginatus ticks [9], as tick-borne infection, transmitted to humans [2].

Finally, Papa et al. [20] mentioned the potential of pathogen transmission by $H$. parva in Greece i.e. novel tick-borne phlebo viruses. Ozubek and Aktas [19] stated the occurrence of Ovine piroplasmosis and Theileria annulata in cattle from Turkey, found on ticks including H. parva. Keskin et al. [16] pointed out to the transmission of several tick-borne pathogens i.e. Borrelia burgdorferi, Rickettsia hoogstraalii and CCHF virus by $H$. parva tick while infesting humans.

Further studies concern the identification of pathogens carried by these three ticks species in Lebanon.

Acknowledgements We are thankful to Dr. Marta Saloña-Bordas for helping with the identification of the species $H$. punctata at University of Reading, to Dr. Riad Zaghloul from Bellevue Hospital in Mansourieh Lebanon and Dr. Michel F. Sawan for providing us with the tick specimens.

\section{Compliance with Ethical Standards}

Conflict of interest The authors declare that they have no conflicts of interest.

Human and animal rights This article does not contain any studies with human participants or animals performed by any of the authors.

Open Access This article is licensed under a Creative Commons Attribution 4.0 International License, which permits use, sharing, adaptation, distribution and reproduction in any medium or format, as long as you give appropriate credit to the original author(s) and the source, provide a link to the Creative Commons licence, and indicate if changes were made. The images or other third party material in this article are included in the article's Creative Commons licence, unless indicated otherwise in a credit line to the material. If material is not included in the article's Creative Commons licence and your intended use is not permitted by statutory regulation or exceeds the permitted use, you will need to obtain permission directly from the copyright holder. To view a copy of this licence, visit http://creativecommons.org/licenses/by/4.0/.

\section{References}

1. Andersson M, Marga G, Banu T, Dobler G, Chitimia-Dobler L (2018) Tick-borne pathogens in tick species infesting humans in Sibiu County, central Romania. Parasitol Res 117(5):1591-1597
2. Anton E, Nogueras M, Pons I, Font B, Munoz T, Sanfeliu I, Segura F (2008) Rickettsia slovaca infection in humans in the northeast of Spain: Seroprevalence Study. V-Borne Zoo Dis 8(5):689-694

3. Blanda V, Torina A, La Russa F, D'Agostino R, Randazzo K, Scimeca S, Giudice E, Caracappa S, Cascio A, de la Fuente J (2017) A retrospective study of the characterization of Rickettsia species in ticks collected from humans. Ticks Tick-borne Dis 8(1):610-614

4. Briciu V, Titilincu A, Tatulescu D, Carstina D, Lefkaditis M, Mihalca A (2011) First survey on hard ticks (Amblyommidae) collected from humans in Romania: possible risk for tick-borne diseases. Exp Appl Acarol 54(1):199-204

5. Briciu VT, Meyer F, Sebah D, Ţăţulescu DF, Coroiu G, Lupşe M, Carstina D, Mihalca AD, Hizo-Teufel C, Klier C, Huber I, Fingerle V (2014) Real-time PCR-based identification of Borrelia burgdorferi sensu lato species in ticks collected from humans in Romania. Ticks Tick-borne Dis 5(5):575-581

6. Bursali A, Tekin S, Keskin A, Ekici M, Dundar E (2011) Species diversity of ixodid ticks feeding on humans in Amasya, Turkey: seasonal abundance and presence of Crimean-Congo hemorrhagic fever virus. J Med Entomol 48(1):85-93

7. Dabaja M, Tempesta M, Bayan A, Vesco G, Greco G, Torina A, Blanda V, La Russa F, Scimeca S, Lelli R, Ezzedine M, Mortada H, Raoult D, Fournier P, Mortada M (2017) Diversity and distribution of ticks from domestic ruminants in Lebanon. Vet Italiana 53(2):147-155

8. de la Fuente J, Estrada-Peña A, Venzal J, Kocan K, Sonenshine D (2008) Overview: ticks as vectors of pathogens that cause disease in humans and animals. Front Biosc 13:6938-6946

9. Estrada-Peña A, Jongejan F (1999) Ticks feeding on humans: a review of records on human-biting Ixodoidea with special reference to pathogen transmission. Exp Appl Acarol 23(1):685-715

10. Estrada-Peña A, Bouattour A, Camicas J-L, Walker A (2004) Ticks of domestic animals in the mediterranean region: a guide to identification of species. University of Zaragoza, Spain 56-58:62-64

11. Garben F, Vos H, van Bronswijk J (1981) Haemaphysalis punctata Canestrini and Fanzago 1877, a tick of pastured seadunes on the island of Texel. Acarologia 23(1):19-25

12. García-Sanmartín J, Barandika JF, Juste RA, García-Pérez AL, Hurtado A (2008) Distribution and molecular detection of Theileria and Babesia in questing ticks from northern Spain. Med Vet Entomol 22:318-325

13. Grech-Angelini S, Stachurski F, Uilenberg G (2016) Ticks (Acari: Amblyommidae) infesting cattle and some other domestic and wild hosts on the French Mediterranean island of Corsica. Paras Vectors 9:582-592

14. Hosseini-Chegeni A, Telmadarraiy Z, Salimi M, Arzamani K, Banafshi O (2014) A record of Haemaphysalis erinacei (Acari: Amblyommidae) collected from Hedgehog and an identification key for the species of Haemaphysalis occurring in Iran. Persian J Acarol 3(3):203-215

15. Kassis I, Ioffe-Uspensky I, Uspensky I (1997) Kosta M (1997) Human toxicosis caused by the tick Ixodes redikorzevi in Israel. Isr J Med Sci. 33(11):760-761

16. Keskin A, Keskin A, Bursali A, Tekin S (2015) Ticks (Acari: Ixodida) parasitizing humans in Corum and Yozgat provinces Turkey. Exp Appl Acarol 67(1):607-616

17. Mariana A, Zuraidawati Z, Ho TM, Mohd Kulaimi B, Saleh I, Shukor MN, Shahrul-Anuar MS (2008) Ticks (Ixodidae) and 
other ectoparasites in Ulu Muda forest reserve, Kedah, Malaysia. Southeast Asian J Trop Med Public Health 39:496-506

18. Orkun O (2018) Molecular Characterization Based on $16 \mathrm{~S}$ rDNA Phylogeny of Some Ixodid ticks in Turkey. Turkiye Parazitol Derg 42(1):122-129

19. Ozubek S, Aktas M (2017) Molecular and parasitological survey of ovine piroplasmosis, including the first report of Theileria annulata (Apicomplexa: Theileridae) in sheep and goats from Turkey. J. Med Entomol 54(1):212-220

20. Papa A, Kontana A, Tsioka K, Saratsis A, Sotiraki S (2017) Novel phlebovirus detected in Haemaphysalis parva ticks in a Greek island. Ticks Tick-borne Dis 8(1):157-160

21. Papadopoulos B, Morel P, Aeschlimann A (1996) Ticks of domestic animals in the Macedonia region of Greece. Vet Parasitol 63:25-40

22. Parola P, Raoult D (2001) Ticks and tickborne bacterial diseases in humans: An emerging infectious threat. Clin Infect Dis 32(6):897-928
23. Rubel F, Brugger K, Pfeffer M, Chitimia-Dobler L, Didyk Y, Leverenz S, Dautel H, Kahl O (2016) Geographical distribution of Dermacentor marginatus and Dermacentor reticulatus in Europe. Ticks Tick-borne Dis 7(1):224-233

24. Tirosh-Levy S, Gottlieb Y, Apanaskevich D, Mumcuoglu K, Steinman A (2018) Species distribution and seasonal dynamics of equine tick infestation in two Mediterranean climate niches in Israel. Paras Vectors 11(546):1-10

25. Vatansever Z (2017) Haemaphysalis parva (Neumann). In: Estrada-Peña A, Mihalca D, Petney T (eds) Ticks of Europe and North Africa. Kars, Turkey, pp 259-263

26. Vatansever Z, Gargili A, Aysul N, Sengoz G, Estrada-Peña A (2008) Ticks biting humans in the urban area of Istanbul. Parasitol Res 102(1):551-553 